\title{
Instructional Leadership as an Effort to Increase Teacher Professionalism in the Industrial Revolution Era 4.0
}

\author{
Bahtiar Agung Pambudi \\ Al - Izzah High School \\ Batu City, Indonesia \\ ombahtiar@gmail.com
}

\author{
Imam Gunawan \\ Department of Educational Administration \\ Universitas Negeri Malang, Indonesia \\ imam.gunawan.fip@um.ac.id
}

\begin{abstract}
The principal has a number of tasks and roles that become his responsibility beyond his ability as a manager, educator administrator, supervisor, motivator, innovator, entrepreneurial developer and leader. Principals are required to be able to have the leadership skills of learning in carrying out the learning function at school. So that the success of the learning process in schools is the responsibility of the principal not only the teacher. In this study the method of data retrieval is used by using interview, observation, and study documentation techniques. Based on the analysis conducted, the results of the study are: (a) effective learning leadership strategies; (b) learning leadership strategies in preparing teacher professionalism abilities in the industrial revolution era 4.0.
\end{abstract}

Keywords: instructional leadership, school principal, teacher professionalism, industrial revolution 4.0

\section{INTRODUCTION}

The increasingly rapid flow of technological development from the period to the present in 2019 is called the era of the industrial revolution 4.0. as felt by many individuals, this development led to systematic changes in many fields such as in the fields of culture, economics, politics, technology, and education.

The emergence of the industrial revolution $4.0 \mathrm{did}$ not start suddenly but was preceded by the 1.0 revolution marked by production mechanization to support the effectiveness and efficiency of human activities, the industrial revolution 2.0 was characterized by mass production and quality standardization, whereas in industry 3.0 it was characterized by mass adjustments and flexibility Automation-based manufacturing and robots, so far entered in the 4.0 industrial revolution marked by physical cyber and manufacturing collaboration (Hermann et al, 2015; Irianto, 2017). Lifter and Tschiener (2013) put forward the basic principles contained in the industrial revolution 4.0, namely the integration of machines, workflows and systems, by implementing intelligent networks along the chain and production process to control each other independently.

The flow of rapid changes in the era of the industrial revolution 4.0 is not only just hit the fields of economics and technology, to the point of education is also required to prepare to enter this era. The era of the industrial revolution 4.0 has now touched on aspects of education on a massive scale, these changes have begun to emerge significantly such as adjustments to the objectives of education, learning curricula, teaching strategies, school management, administrative processes, assessment and evaluation of learning for change in the current era. So, it directly requires the important role of a school principal who is able to position himself as having the role of instructional leadership in increasing teacher professionalism in the era of the industrial revolution 4.0. Principal learning leadership is an important factor in improving the quality of learning in school organizations. So, the teacher is also required to develop attractive learning media and use good learning media in line with technological developments in this era. In addition to mastering technology, teachers must also be able to explain how to apply the technology to their daily lives.
With changes in many sectors and the education sector also affected by these changes, it is important that a learning leader is expected to have independence and ability to codify and determine the direction of the organization in school development efforts by synergizing all the resources and potentials contained in the institution so that it will produce effective, efficient, productive and certainly optimal learning.

Teacher professionalism also needs to be supported by the principal's learning leadership. according to Government Regulation No. 19 of 2005, that professional teacher competency must have: (a) pedagogical competence, (b) personality competency, (c) professional competence; and (d) social competence. Teacher professionalism standards are also conveyed by Bush \& Glover (2003) by defining that professional standards are important knowledge needed, professional teachers always try to create communicative learning between students and teachers, teachers have the skills, attitudes, and abilities to demonstrate learning content by packaging material that is easy to understand, have skills in using learning media, and are always oriented to maximum service. This article will explain in full the picture of the efforts of principals in creating effective learning leadership strategies, as well as learning leadership strategies in preparing the professionalism skills of teachers in the era of the industrial revolution 4.0

\section{METHOD}

This research was carried out at Al - Izzah High School, Batu City, East Java, Indonesia. In this study the authors used a qualitative approach as data collection and analysis activities. While the techniques used in this study are observation, in-depth interviews, and documentation. In this study, researchers used key informants namely the Principal, Deputy Principal for Field Assessment and Deputy Principal for Curriculum. Then analyzed using stages with data reduction, data display, and data verification. Data reduction is a review in sorting out the data received according to existing field conditions. Data display is the result of reduction arranged structured and displayed in the results of the study, while data verification is an activity of checking the compatibility of the meaning of data obtained from the field to reach strong conclusions. 


\section{THEORITICAL REVIEW}

\section{Learning Leadership}

The understanding of leadership learning itself is an action intended to develop a work environment so that it is productive and satisfying for the teacher, as well as developing the learning conditions and learning outcomes desired by students. So that the main focus of learning leadership is on the improvement and development of learning (Greenfield, 1987: Gorton and Schneider, 1990). As for Soutworth (2002) states that leadership learning is the effort of the Head of School to give strong attention to teaching and learning, including professional learning by teachers according to student development.

Learning leadership is one of the competencies that must be possessed by a school principal. As explained in Regulation of the Minister of National Education (Permendiknas) No. 35 of 2010 which explains the competency of school principals as leaders of learning. The ministerial regulation contains Technical Instructions for Teacher Functional Position and Credit Scores that the effectiveness of school principals is assessed in terms of competency credit: (a) personality and social, (b) leadership learning; (c) school / madrasah development; (d) resource management; (e) school entrepreneurship / madrasa; and (f) supervision of learning. Learning leadership can encourage the creation of an effective, efficient, productive and certainly optimal learning environment.

There is also a definition of learning leadership as conveyed by Hallinger (1993), defining effective learning leadership as: (a) delivering the vision of the school through a poll with the school community and striving for the vision and mission of the school to flourish in its implementation; (b) the school principal uses participatory management by involving stakeholders in school management; (c) the school principal provides support for learning; (d) the school principal monitors the teaching and learning process carried out by the teacher to get more indepth information and is aware of what is going on in the school so that when there are problems in learning will be immediately resolved; (e) the principal acts as a facilitator in various ways so that the principal must be able to know the learning difficulties and be able to help the teacher overcome these learning difficulties.

There are two factors related to learning leadership, namely from external and internal school factors. Ubben \& Hughes, 1992; Rossow (1990) provides two external factors that have a strong influence on learning leadership behavior in schools, namely: (a) community values and expectations; and (b) school institutional structure. which is explained by Kusmintardjo (2014) the demands and expectations of the community in inner-city schools are more for wanting high student achievement, so that the principal spends his time meeting the demands and expectations of the community for high student achievement. in contrast to, in rural schools (rural schools), principals focus on dealing with problems of student behavior as a result of poverty and lack of education awareness from parents of students.

Whereas the internal factors contained in schools that are of concern to learning leadership include: (a) defining the school's mission, and (b) instructional organization, improving instructional practices, improving climate and positive learning in schools (promoting positive school climate) (Hallinger, et al., 1983; Rossow, 1990; Ubben \& Hughes, 1992). So, in other words the internal factor of the headmaster's learning leadership in enhancing learning is the implementation of learning leadership behavior in an effort to manage the internal dimensions of the school so that teachers are encouraged to improve their professionalism in the face of the industrial revolution era 4.0.

Kusmintardjo research results (2003), convey in detail that the role of the principal as a learning leader is: (a) learning leaders as management engineers i.e. learning leaders are able to apply planning, organizing, coordinating and supervising learning techniques, (b) learning leaders as communicators in other words learning leaders must be able to apply motivational and interpersonal communication techniques, as well as familial and religious approaches in an effort to build high work morale among school personnel, (c) learning leaders as clinical practitioners are also required to be able to diagnose learning problems and take innovative and effective actions in efforts to improve the quality of learning processes and learning outcomes in schools, (d) learning leaders as role models able to present himself as a leader who is ready to discuss learning problems with teachers and teachers, and (e) learning leaders as someone who is able to build the impression of an image, namely the principal can articulate goals and missions school.

There are several steps that need to be done by the principal in creating his role in leadership learning. based on the opinion of McEwan (2002) there are at least seven steps of learning leadership, namely: (a) setting learning goals by involving teachers in setting and developing and evaluating learning programs, (b) becoming a resource for staff by collaborating together in developing, improving, and setting programs effective learning, (c) creating a school climate conducive to learning by providing reinforcement to students, (d) communicating the vision and mission of the institution to staff, and (e) conditioning staff to achieve high professionalism, developing the professional abilities of teachers, being positive towards students, staff, and parents of students.

There are several strategies that allow learning leadership to make alternatives in improving and developing teacher professionalism, as stated by Kunandar (2009), namely: (a) listening (listening), complaints, problems or ideas conveyed by the teacher in order to improve his professionalism; (b) clarifying (clarifying) or explain what is desired or intended by the teacher, by asking the question concerned; (c) encourage (encouraging), the principal encourages the teacher to want to restate about something when it is still not clear; (d) presenting, the principal tried to express his perception of what the teacher meant; (e) solving problems (problem solving) together between the principal and the teacher if there are problems faced by the teacher; (f) negotiation (negotiating), between the principal and the teacher to build agreements on the tasks that must be done together or individually; (g) demonstrating, for example, that can be observed and imitated by the teacher; (h) directing (directing), matters relating to the effectiveness of learning; (i) standardizing, adjusting to the teacher; and (j) give reinforcement (reinforcing), on what has been achieved by 
the teacher. Overall implementation of the leadership behavior of school principals can be seen from their ability to manage the internal dimensions of the school so that teachers are encouraged to improve their performance (Kusmintardjo, 2014).

\section{Teacher Professionalism}

Increasing student academic achievement is very closely related to the professionalism abilities possessed by teachers to carry out learning activities or the process of transfer of knowledge to students in class. not only that professional teachers must also be able to master teaching materials and understand the characteristics of each student. Quoted on the website ppg.ristekdikti.go.id Intan explained that the need to prepare teachers to face the industrial revolution era 4.0, he said that "Educational problems cannot be solved now in the past, so speak in front of the class according to the relevance of current conditions," the education curriculum also does not need to be changed, but only adjusts with relevant events.

According to the Big Indonesian Dictionary (KBBI) the meaning of the word professional is a profession that requires special intelligence to carry it out. While the notion of professionalism is related to quality, quality, and behavior that are characteristic of a profession or professional person. According to Wahyudi (2012) professional teachers are teachers who are able to manage themselves in carrying out their daily tasks.

In Law of the Republic of Indonesia number 14 of 2005 concerning Teachers and Lecturers. A professional teacher needs to meet four predetermined competencies, namely: (a) pedagogic competence, namely the ability of teachers to manage learning includes an understanding of learning materials, learning planning, learning implementation, evaluating student learning outcomes, and being able to develop and actualize the various potentials of students; (b) personality competence is a personality ability that is steady, stable, mature, wise and wise, authoritative, noble, able to be an example for students and society, and able to evaluate one's own performance and be able to develop it sustainably; (c) professional competence, namely the ability of teachers in mastering the material broadly and deeply, and allows guiding students; (d) social competence, namely the ability of teachers to associate effectively with students, as well as fellow educators, education personnel, parents, or guardians of students, and always socialize politely in society, then teachers as part of the community must also be able to communicate verbally and in writing, and skilled in using communication and information technology functionally.

Qusthalani explained in Wahyuni's writing at the Research Center of the Indonesian Parliament's Expertise Research Center that there were at least five competencies that teachers must prepare to enter the Industrial Revolution 4.0 era, namely: (a) teachers must have educational competence, that in era 4.0 internet competency-based learning competencies would be needed as skills that must be owned by a teacher, (b), the teacher must also have competence for technological commercialization, i.e. the teacher must have the competency of entrepreneurship ability to be taught to students of course with technology as its introduction, (c) the teacher must have competence in globalization, that is, the teacher does not stutter to various cultures and able to solve educational problems; d) the teacher must also have competence in future strategies, namely having the ability to predict precisely what will happen in the future and the strategy, by way of joint-lecture, joint-research, jointresources, staff mobility, and rotation, and (e) teachers also need to have competent counselors, namely the competence of teachers to understand that in the future the problem of students is not only difficult to understand teaching materials, but also related to psychological problems due to the times.

Whereas Sagala (2009) mentions that there are five attitudes displayed by professional teachers, namely: (a) the teacher has the desire to always display behaviors that are close to the ideal standard, (b) the teacher will always improve and maintain the professional image, (c) the teacher has the desire to always improve, improve, and develop the quality of knowledge and skills, (d) professional teachers will always pursue the quality and ideals in their profession, and (e) professional teachers will always have pride in their profession. So, it can be concluded that professional teachers are people who have special abilities and expertise in their fields and have experience in teaching.

In the era of the industrial revolution 4.0, teachers are also required to have supported competencies in dealing with the progress of this era. In enhancing teacher professionalism efforts, there is also a positive influence from the role of the Teacher Working Group (KKG) and the Subject Teachers' Deliberation (MGMP) in developing teachers to have a professional attitude as a teacher. The existence of training and sending of teachers to follow teacher training and the existence of ongoing supervision activities carried out by the principal will have positive results on increasing the professionalism of the teacher.

\section{RESULTS AND DISCUSSION}

\section{Effective Learning Leadership Strategies}

Learning is said to be effective when the objectives of learning can be achieved properly in accordance with predetermined learning objectives. Learning itself implies a process of interaction between a teacher and students with the existence of learning resources in the learning environment with the aim of the process of transferring knowledge and knowledge to students.

In this case the leadership strategy used in the effort to create effective learning at Al-Izzah High School which is felt to bring positive results to the realization of effective learning, based on observations and interviews conducted by the author in the field found the results of research, namely "the principal involved teachers in preparation of learning curricula starting from the making of lesson plans, RPS, syllabus to evaluation of learning assessment. Not only that the principal as a person who has a learning leadership also participates in collaboration and exchange opinions with the teacher in an effort to develop, establish, and improve the learning program that will be implemented by the teacher".

Based on interviews conducted with the Vice Principal for Curriculum, he stated that "on several occasions the principal does not forget to deliver and always reminds teachers and other staff to always stick to the vision and mission set by the institution so that the 
goals of the institution can achieved together. Whereas the relationship between the school and the community is always well maintained such as a meeting with the guardians of students and regularly communicating to the homeroom teacher to always provide information on student development to the guardians of students regularly or periodically. The existence of Tausiah Morning (TM) activities at Al-Izzah High School has created an opportunity for principals to encourage teachers to always create quality learning. Likewise, supervision activities are carried out routinely and scheduled to create the quality of teaching conducted by the teacher running effectively". So, it can be concluded that leadership learning in an effort to create effective learning has been implemented well by the school principal by using strategies that have been well implemented. So the leadership of learning by the principal is in accordance with his role, namely as a learning leader as the theory conveyed by Kusmintardjo (2003), namely; the principal as a management engineer, communicator, clinical practitioner, role model, and also someone who is able to build the impression of an image in learning leadership.

\section{Learning Leadership Strategies in Preparing Teacher Professionalism Capabilities in the Industrial Revolution Era 4.0.}

Quoted on page seconds. com data from UNESCO on the Global Education Monitoring (GEM) Report in 2016 shows the competence of Indonesian teachers is ranked 14th out of 14 developing countries in the world. While education in Indonesia ranks 10th out of 14 developing countries. So, it is felt important to develop and improve teacher competence. Then there is a good learning leadership strategy in

Learning leadership strategy in preparing the professionalism skills of teachers in Al-Izzah Batu City High School to deal with the era of the industrial revolution 4.0 obtained interviews results that principals implement elearning systems as an electronic learning system using technology. The use of the system is considered to have a positive effect on student learning outcomes. Not only that, the principal also emphasizes the use of technology as a learning leadership strategy in conducting supervision and creating effective learning. As seen from the application of the online learning evaluation system used by teachers. This is an implementation of the principal's efforts to encourage teachers to develop their abilities in the use of technology.

It was said by the Deputy Principal in the Field of Assessment, "learning leadership is applied by principals by giving special time to teachers to conduct consultations in an effort to solve problems regarding their ability to use technology that supports learning experienced by teachers. So it can be concluded that the leadership learning of principals in an effort to prepare the professionalism skills of teachers in the era of the industrial revolution 4.0 has been run well by the principal Evidenced by the results of interviews with informants who reinforce the opinion of Kunandar (2009), that the principal applies a strategy to encourage (encouraging) teachers to use technology to improve the effectiveness of learning, Directing (directing) on matters relating to the effectiveness of learning conducted by teachers, and school principals provide reinforcement, to teachers by always emphasizing the use of technology as one of the learning leadership strategies in conducting supervision and creating effective learning.

\section{CONCLUSION}

This effort to increase teacher professionalism in the era of the industrial revolution 4.0 emphasizes the determination of learning leadership strategies by school principals in helping teachers create effective learning. In the era of the industrial revolution 4.0, teachers are also required to develop attractive learning media and to use good learning media in line with technological developments in this era. In addition to mastering technology, teachers must also be able to explain how to apply the technology to their daily lives. Learning leadership is also an attempt by the Principal to give strong attention to teaching and learning, including professional learning by the teacher according to student development.

There are several strategies used by principals in creating effective learning, namely: (a) the principal as a management engineer such as the supervision activities carried out routinely and scheduled in order to create the quality of teaching carried out by the teacher running effectively, (b) learning leaders as communicators such as also participate in collaboration and exchange opinions with teachers in efforts to develop, establish, and improve learning programs that will be implemented by teachers, (c) learning leaders as clinical practitioners such as school principals involve teachers in the preparation of learning curricula starting from making lesson plans, RPS, syllabus to evaluating learning assessment, (d) learning leaders as role models are able to present themselves as leaders who are ready to discuss the problem of learning with teachers and teachers, and (e) learning leaders as someone who is able to build the impression of an image, on several occasions the principal every morning does not forget to convey and always reminds teachers and other staff to always stick to the vision and mission that has been determined by the institution so that the goals of the institution can be achieved together.

While the principal's leadership learning strategy in an effort to prepare the professionalism of teachers in the industrial revolution era 4.0 has been well implemented by the school principal. In implementing the strategy, a) encouraging (encouraging) teachers to use technology to improve the effectiveness of learning, b) directing (directing) on matters relating to the effectiveness of learning undertaken by the teacher, c) as well as the principal giving reinforcement (reinforcing), the teacher by always emphasizing the use of technology as one of the learning leadership strategies in conducting supervision and creating effective learning.

\section{REFERENCES}

[1] Bush, T. \& Glover, D. 2003. School Leadership: Concept and Evidence. Nottingham: National College for School Leadership.

[2] Detik. 2018. Mengkritisi Kompetensi Guru. Retrieved 2 July 2019, from https:// news.detik.com/kolom/d-3741162/ mengkritisi-kompetensi-guru.

[3] Gorton, R.A., \& Schneider, G.T. 1991. Schools- Based Leadership: Challenges and Opportunities. Dubuque, Iowa: Wim C. Brown Company Publisher. 
[4] Greenfield, W. D. 1987. Instructional Leadership: Concepts, Issue, and Controversies. Boston: Allyn and Bacon.

[5] Hallinger, P. 2003. Leading Educational Change: Reflections on the Practice of Instructional and Transformational Leadership. Cambridge Journal of Education, 33(3), 35-70

[6] Hallinger, P., \& Leithwood, K. 1994. Introduction: Exploring the Impact to Principal Leadership. School Effectiveness and School Improvement: An International Journal of Research, Policy, and Practice, 5(3), 206-218.

[7] Hermann, M., Pentek, T., \& Otto, B. 2016. Design Principles for Industry 4.0 Scenarios. Presented at the 49th Hawaiian International Conference on Systems Science.

[8] Kunandar. 2009. Guru Profesional Implementasi Kurikulum Tingkat Satuan Pendidikan dan Sukses dalam Sertifikasi Guru. Jakarta: Rajawali Press.

[9] Kunandar. 2009. Guru Profesional Implementasi Kurikulum Tingkat Satuan Pendidikan dan Sukses dalam Sertifikasi Guru. Jakarta: Rajawali Press.

[10] Kusmintardjo. 2014. Kepemimpinan Pembelajaran oleh Kepala Sekolah. Manajemen Pendidikan, 24(3), 203-212.

[11] Lee, J., Lapira, E., Bagheri, B., \& Kao, H. 2013. Recent Advances and Trends in Predictive Manufacturing Systems in Big Data Environment. Manuf. Lett, 1(1), 38-41.

[12] Liffler, M., \& Tschiesner, A. 2013. The Internet of Things and the Future of Manufacturing. McKinsey \& Company.

[13] McEwan, E. K. 2002. 7 Steps to Effective Instructional Leadership. California: Corwin Press.

[14] Peraturan Menteri Pendidikan Nasional Nomor 35 Tahun
2010 tentang Petunjuk Teknis Jabatan Fungsional Guru dan Angka Kreditnya. Jakarta: Kemdiknas.

[15] Ristekdikti. 2018. Masuki Era Revolusi Industri 4.0, Tantangan Guru Makin Kompleks. Retrieved 2 July 2019, from http://ppg.ristekdikti.go.id.

[16] Rossow. L. F.1990. The Principalship Dimensions in Instructional Leadership. Boston: Allyn and Bacon.

[17] Sagala, $\quad$ H. S. 2009. Kemampuan Profesional Guru danTenaga Kependidikan. Bandung: Alfabeta.

[18] Soutworth, G. 2002. Instructional Leadership in School: Reflection and Empirical Evidence. School Leadership and Management, 22(1), 73-92.

[19] Sumarsono, R. B. Upaya Peningkatan Mutu Sekolah Melalui Penguatan Peran Kepemimpinan Pembelajaran Oleh Kepala Sekolah. Malang: Jurusan Administrasi Pendidikan Fakultas Ilmu Pendidikan Universitas Negeri Malang.

[20] Ubben, G.C., \& Hughes, L.W. 1992. The Principal: Creative Leadership for Effective Schools. Boston: Allyn and Bacon

[21] Undang-undang Republik Indonesia Nomor 14 tahun 2005 tentang Guru dan Dosen. Bandung: Citra Umbara.

[22] Wahyudi, I. 2012. Pengembangan Pendidikan, Strategi Inovatif \& Kreatif Dalam Mengelola Pendidikan Secara Konprehensif. Jakarta: PT Prestasi.

[23] Wahyuni, D. 2010. Peningkatan Kompetensi Guru Menuju Era Revolusi Industri 4.0. Jakarta: Pusat Penelitian Badan Keahlian DPR RI. 